\title{
Factors of Recidivism among Reintegrated Inmates in Kenya
}

\author{
Dr. Evans M. Oruta (Ph D) \\ Lecturer, Department of Criminology and Social Work \\ Masinde Muliro University of Science and Technology, Kenya: Email: eoruta@mmust.ac.ke \\ Prof. Willem Luyt \\ Professor, Department of Corrections Management, School of Criminal Justice, College of Law, University of \\ South Africa. Email: wfmluyt@unisa.ac.za
}

\begin{abstract}
Statistics throughout the globe suggest that most prisoners coming out of prison are likely to be re-sentenced within three years of their release. Research continue to find that almost 80 percent of prisoners are likely to be rearrested within a decade of being free. Rearrests around the world may occur within the first year of release if no support is given to the offender. High recurrence rates mean more violence, more victims, and more criminal justice system stress. Recidivism is a technical term which, when loosely understood, bypasses the major problem it faces, the problem of continuity of criminal behaviour. Recidivism remains a concern for Kenyan authorities. In this article we examine the influence of offender characteristics, offender reintegration, and community perceptions and attitudes regarding recidivism in Kakamega County, Kenya. The study applied a survey research design. The study adopted a survey research design in which 384 recidivists were sampled to take part in the study as respondents. Besides the recidivist, 25 Prison Officers, 13 Probation Officers, 27 family members of recidivists, and 18 community members from the neighbourhoods of recidivists bringing the target sample to 467 respondents. Both probabilistic and non-probabilistic sampling techniques were used in sample selection. Data from respondents was collected using a questionnaire that was tested for validity and reliability prior to the actual data collection. Factor analysis was used to ascertain validity while Cronbach's Alpha coefficient of reliability was used to ascertain reliability of the questionnaireFindings reveal a statistically significant relationship between offender characteristics and recidivism, while offender reintegration and community perceptions and attitudes towards offenders are found to greatly influence recidivism. From the study, it is recommended that correctional officers use the actuarial risk assessment model to predict the future probability of recidivism. It is recommended that the various correctional stakeholders develop an integrated approach that specifically targets successful re-entry of offenders upon release, while programmes must be developed to target community awareness to desist from stigmatising ex-offenders.
\end{abstract}

Keywords: Recidivism; Kenya prisons; reintegrated inmates; Kakamega County; offender characteristics; community awareness; actuarial risk assessment model

DOI: $10.7176 / \mathrm{JLPG} / 118-14$

Publication date: February $28^{\text {th }} 2022$

\subsection{INTRODUCTION}

Recidivism in Kenya is a growing challenge (Wasike, 2013: xi; 42). High recidivism trends in Kenya concern policymakers. The Kenya Prisons Service is mandated to rehabilitate inmates (Republic of Kenya, 2012: 8). Inmates commit crimes soon after being released, despite rehabilitation programmes being offered (Wasike, 2013: 3). Little has been documented about integrated offender management processes in Kenya, while offender challenges after release also receive little attention (Oruta, 2019:3).

With this short, but important background in mind, transitional challenges that offenders face upon release must be addressed to ensure integrated offender management. To achieve that, the correlates of recidivism among Kenyan inmates had to be established through research into the role of inmate reintegration, the influence of offender characteristics, and the influence of the community perceptions and attitudes.

\subsection{RECIDIVISM IN THE LITERATURE AND IN KENYA}

Editorial limitations prevent the authors from elaborate literature discussions. Broader important aspects from the literature study are additionally included in the research result discussions to provide more clarity, where applicable.

Different definitions occur in the literature, classifying recidivism as reoffending, re-arrest, re-prosecution, or reconviction. Broader definitions include technical violations, like failing drug tests or absence at meetings (Malz, 2001: 21). Theoretically, recidivism remains a relapse into crime after being released from incarceration. In this review, recidivism is defined as relapse that contributes to re-arrest, re-conviction or re-incarceration (Oruta, 2019: 38).

The prison environment bring structural conflict between officials and inmates owing to frequent 
misunderstandings and strict rule enforcement, contributing to recidivism (Cunneen \& Luke, 2007: 205; Fhooblall, Chitto \& Bholoa, 2011: 61). The perception of officials is that offenders deserve to be punished, while offenders see officials as evil opposition. Legitimate force is an inadequate means of maintaining law and order (Sykes, 1958: 27; Brown, 2012: 569; Cunneen \& Luke, 2007: 199). Order is influenced through conflict between officials and offenders. Although inmates recognise the authority of officials, they do not always feel morally bound to obey them. These incarceration conditions, or the pains of imprisonment, including multiple deprivations make the inmates adopt criminal strategies to relieve or protect themselves. Often these strategies constitute crime, leading to recidivism, even while incarcerated already.

Incarceration leads to the seduction of criminal lifestyles and ultimately to becoming persistent offenders. Within the inmate community, first-time offenders regard hardened criminals as role models. They become attracted, corrupted and contaminated by the influences of these hardened criminals who socialise them with these pro-criminal attitudes and values. According to La Vigne, et al (2014: 339), crime, like other behaviours, is a learnt trait.

The tag "convicted felon" is an important hurdle that contributes to recurring crime (Chiricos, Barrick, Bales \& Bountrager, 2007: 569). The stigma itself causes recurrence. Those most prone to recur (men, marginalised ethnic groups, and those with already extravagant criminal records) are less affected by incarceration (Chiricos, Barrick, Bales, \& Bontrager, 2007:568).

Criminologists have long recognised the significance of local history in establishing crime theories (Ainsworth, 2001: 523). Research has largely overlooked the effect of communities on recurrence (Olusanya \& Gau, 2012: 169). However, Garvin, Cannuscio \& Bran (2013: 202) demonstrate the influence of the perception of neighbourhood crime by individuals.

In Kenyan context, recidivism originated from the British approach (Wasike, 2013: 2). Kenyan offenders have a $75 \%$ likelihood of reoffending, with $50 \%$ within two years after release (Oruta, Omosa \& Lumumba, 2017: 101). Theft is the main crime category for reoffending, with few murder cases contributing. Crime by exinmates are increasing, while rehabilitation programmes are reported to be ineffective in recidivism prevention. A major concern is the social and economic cost related to recidivism. (Wasike, 2013: 3).

\subsection{RESEARCH AIM}

Recidivism research is essential against the backdrop of growing prison overcrowding, systemic challenges, and the general failure of rehabilitation (Rosario, 2010: 1). The research aim is to establish the correlates of recidivism among released inmates in Kakamega County, Kenya. This is addressed through the study findings and their explanations, contextualised by descriptive and inferential statistics. To explain the respondents' demographic characteristics, descriptive statistics are evaluated and displayed through several distribution means (tables, frequencies, and percentages). Inferential statistics utilised include the Pearson Product Moment Correlation Coefficient, multiple regression testing, t-test, and ANOVA. Statistical analysis was completed using the SPSS programme.

\subsection{Objectives of the investigation}

The objectives appear below and are discussed separately in that sequence. They are:

- Examining the relationship between offender characteristics and recidivism;

- Establishing the role of offender reintegration on recidivism; and,

- Determining the influence of community perceptions and attitudes on recidivism.

Quantitative data of every objective is analysed first, followed by a qualitative analysis. Importantly, hypothesis testing is conducted for each objective and a decision made depending on significant levels. Findings from each objective are then presented through available means, like frequency tables and graphs, followed by interpretation, discussion, and, where applicable, comparison.

\subsection{TESTING DATA CHARACTERISTICS}

Data quality is crucial to assess whether information can serve its purpose in a particular context. The five major traits in data quality are accuracy, completeness, reliability, relevance, and timeliness (Sarfin, 2021: 1). Below we discuss accuracy through sampling adequacy testing, and reliability through normality testing.

\subsubsection{Sampling adequacy and correlation}

Sampling adequacy stems from the Kayser-Meyer-Olkin (KMO) sampling adequacy test to check whether the information is suitable for evaluation. Field (2009: 247) and Hutcheson \& Sofroniou (1999: 211) note that adequacy values above 0.9 are superb. Values from 0.8 to 0.9 are high, while values from 0.7 to 0.8 are great. Values from 0.5 to 0.7 are regarded as average. Smith (2018: 429) propose a limit of 0.5 .

The correlation matrix is tested through Bartlett's Sphericity Analysis to analyse whether associations exist, or whether the equation is an identity matrix (when all correlation coefficients would be zero).

Table 1 below provides an analysis of the test of sampling adequacy and sphericity of data. Findings show 
that the data is statistically adequate with a KMO value of 0.841 . Also, Barlett's Analysis produces a highly significant outcome, which is below 0.001 .

Table 1: Test of Sampling Adequacy and Sphericity of data

\begin{tabular}{|l|l|r|}
\hline Kaiser-Meyer-Olkin Measure of Sampling Adequacy & .841 & \\
\hline Bartlett's Test of Sphericity & Approx. Chi-Square & 31990.995 \\
\cline { 2 - 3 } & Df & 2893 \\
\cline { 2 - 3 } & Sig. & .000 \\
\hline
\end{tabular}

Source: Field data, (2018)

1.5.2 Testing normality

Univariate normality is analysed by merging responses and conducting the Kolmogorov-Smirnov $\mathrm{Z}$ test and the Shapiro-Wilk D test on the total factor scores (see Table 2). Both statistical procedures analyse whether the distribution deviates from a normal distribution. Findings reveal that the data does not deviate from the normal distribution.

Table 2: Test for Normality in data distribution $(\mathrm{N}=329)$

\begin{tabular}{|l|r|r|r|r|r|r|}
\hline & \multicolumn{2}{|c|}{ Kolmogorov-Smirnov } & \multicolumn{3}{c|}{ Shapiro-Wilk } \\
\hline & Statistic & Df & \multicolumn{1}{|c|}{ Sig. } & \multicolumn{1}{c|}{ Statistic } & \multicolumn{1}{c|}{ Df } & Sig. \\
\hline Socio-demographic factors & .133 & 45 & .001 & .894 & 45 & .003 \\
\hline Individual characteristics & .139 & 45 & .000 & .885 & 45 & .001 \\
\hline Community influence & .146 & 45 & .004 & .911 & 45 & .004 \\
\hline Reintegration issues & .137 & 45 & .000 & .909 & 45 & .000 \\
\hline
\end{tabular}

\section{Source: Field data, (2018)}

Both tests indicate that the data is normally and uniformly distributed. Such normal and uniform distribution allows for the use of statistical techniques that assume normality and uniformity of data distribution, such as ANOVA, Pearson Product Moment Correlation Coefficient and Regression, and to test hypotheses more accurately.

\subsubsection{The Respondents}

The study targets 467 respondents. They comprise of:

- 384 recidivists serving various sentences in three Kakamega County prisons (Shikusa Main, Kakamega Main, and Kakamega Women);

- 25 prison officials;

- 13 probation officials;

- 27 family members of recidivists; and,

- 18 community members from the recidivists' neighbourhoods.

Eventually, 412 respondents participate in the study ( $88.22 \%$ response rate). A response rate of over $80 \%$ is highly significant for generalisation of findings (Sounders, Lewis and Thornhill, 2009: 197).

\subsection{QUANTITATIVE ANALYSIS OF RECIDIVIST DATA}

Demographics

Recidivists represent 329 of the eventual respondents. In this section, focus is placed on their gender, age, education, religion, employment status before incarceration, and current caregivers of recidivists that had children at the time of conviction. These factors are depicted in the literature as having a fundamental influence on recidivism.

With respect to the gender of recidivists, $90.58 \%$ are male and $9.42 \%$ are female, confirming that there are more male recidivists in Kakamega County prisons. This is in line with the general trend in Kenya where more males than females are being processed through the criminal justice system. In 2017, there were 16371 male and 1453 female inmates with previous conviction records, totalling 17826 recidivists inside prisons (Kenya National Bureau of Statistics, 2018:267). Findings regarding recidivists' age are presented in Table 3.

Table 3: Age of recidivist respondents

\begin{tabular}{|l|r|r|}
\hline \multicolumn{1}{|c|}{ Age } & Frequency & \% \\
\hline $18-25$ years & 78 & 23.71 \\
\hline 26-35 years & 96 & 29.18 \\
\hline 36-45 years & 65 & 19.76 \\
\hline 46-55 years & 51 & 15.50 \\
\hline Over 55 & 39 & 11.85 \\
\hline Total & $\mathbf{3 2 9}$ & $\mathbf{1 0 0 . 0 0}$ \\
\hline
\end{tabular}

Source: Field data, (2018)

Findings reveal that $29.18 \%$ of respondents are between 26 and 35 years of age, while $23.71 \%$ are aged between 18 and 25 years. In the study, most recidivists are youthful offenders below 35 years. Apart from 
hampering the socio-economic development of the country, incarceration at a young age contribute to future crime pathways (Sampson \& Laub, 1993: 19; Western, Kling, \& Weinman, 2001: 413).

The marital status of respondents is presented in Graph 1. Findings show that $52.28 \%$ of the respondents are married, while $24.62 \%$ are separated, $12.77 \%$ are single, $7.6 \%$ are divorced and $2.74 \%$ are widowed. Most recidivists have family responsibilities, as $72.64 \%$ of respondents had minor children prior to incarceration. Incarceration strains their ability to provide for their families. It creates pathways to family fragmentation, including children with antisocial personality disorders resulting from a lack of parental supervision and provision (Johnson, Cohen, Chen, Kasen and Brook, 2006: 579).

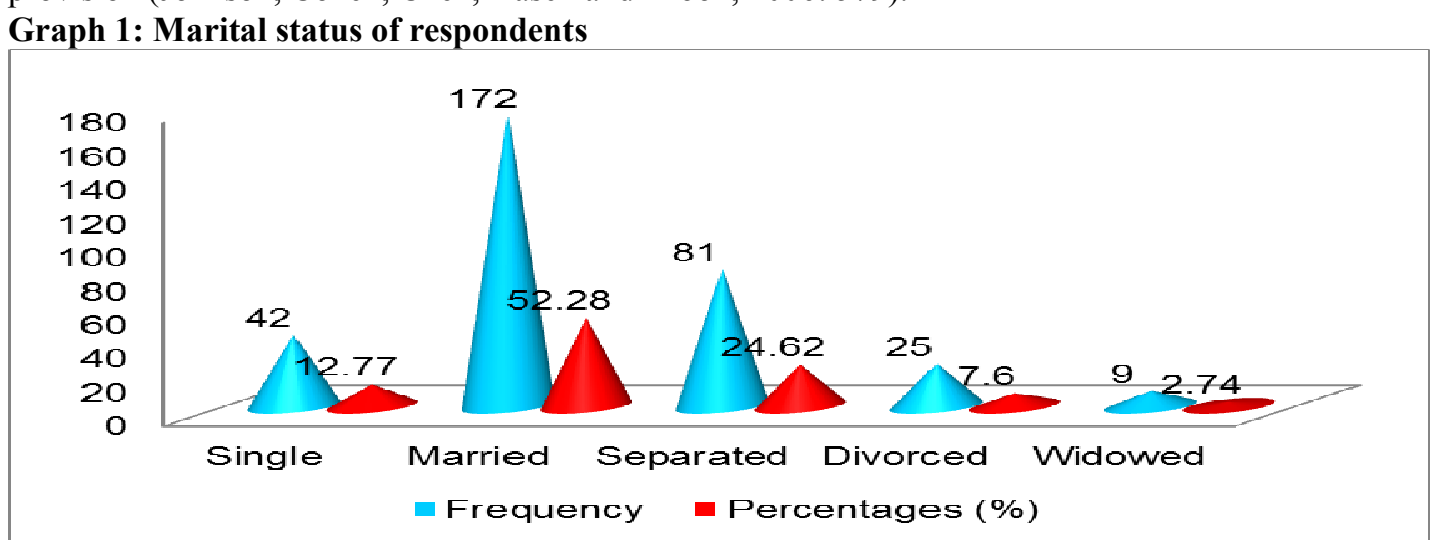

Source: Field data, (2018)

Regarding level of education, findings show that $28.95 \%$ of respondents have primary school education, while $24.46 \%$ have secondary school education. Results show that $19.19 \%$ of respondents have tertiary levels of education, $14.59 \%$ have vocational/technical education, and $12.1 \%$ have no formal education. Most recidivists are literate people and should be able to determine between right and wrong. Thus, lack of knowledge may not be the main reason for repeat offending, which leads us to investigate other individual characteristics and their role in recidivism.

Concerning religious beliefs, $63.53 \%$ of respondents are Christians, $24.62 \%$ are Muslims, and $11.85 \%$ are from other religious faiths, including non-believers. Seen that more than $90 \%$ of recidivists have religious backgrounds, socialisation and other environmental factors may rather explain the departure in character from religious values instilled in believers to what is practiced in the real world.

Employment status statistics prior to incarceration show that $44.07 \%$ of the respondents were self-employed, while $29.79 \%$ were unemployed. Also, $26.14 \%$ of the respondents were in formal employment. Prior to incarceration, most of the recidivists were economically productive individuals. Bearing in mind that most recidivists $53.95 \%$ are in custody as a result of offence against property such as malicious damage and theft point to the fact that most recidivists committed offences in the course of attempting to earn a livelihood. Lack of employment is a consistent factor in recidivism or parole/probation violations, and having a criminal record reduces job opportunities (Holzer, 1996: 91).

Children of incarcerated recidivists in the study are lacking at least one parent. Children rely on both parents for guidance. The lack of one parent create gaps that may predispose children to delinquent trajectories (Siegel \& Welsh, 2009: 92). Some psychological theorists postulate that the lack of one parent during the upbringing may have a negative impact on children in later stages of life (Shoemaker, 2009: 78). The research shows that $27.96 \%$ of the respondents did not have children. This is a very high percentage and lack of parental responsibility may contribute to why the offenders engage in crime. Findings from other studies show that individuals without family responsibilities are more prone to crime as compared to those with responsibilities (Siegel, 2010: 228).

Around $33 \%$ of respondents indicate that their children are left in the care of the children's mothers, while $17.93 \%$ left their children with the children's grandparents. Of female recidivists, $3.65 \%$ left their children with the fathers, and 3.34\% with others, including children homes or willing relatives. The Children's Act (Republic of Kenya, 2001: 23) provides the Director of Children Services with the powers to maintain the welfare of children in a number of ways.

\subsection{RELATIONSHIP BETWEEN OFFENDER CHARACTERISTICS AND RECIDIVISM}

The first objective of the study seeks to investigate the relationship between individual offender characteristics and recidivism among released inmates in Kakamega County. Individual characteristics of interest include gender; age; offence type; number of convictions; the period between incarcerations; type of prison sentence; and drug use prior to incarceration. The following hypotheses are formulated;

$\mathrm{H}_{0} 1$ : Offender characteristics have no significant influence on recidivism 


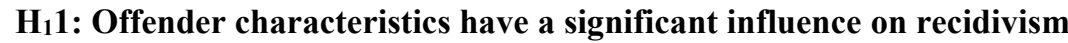

\subsection{QUANTATIVIE ANALYSIS OF THE RELATIONSHIP BETWEEN OFFENDER} CHARACTERISTICS AND RECIDIVISM

Study data relating to individual characteristics and recidivism are subjected to the Pearson Product Moment Correlation Coefficient. Findings are presented in Table 4.

Table 4: Relationship between individual offender characteristics and recidivism

\begin{tabular}{|l|l|r|l|}
\hline & Correlation & Characteristics & Recidivism \\
\hline Characteristics & Pearson Correlation & 1 & \\
\hline & Sig. (2-tailed) & 329 & \\
\hline & $\mathrm{N}$ & $.669(* *)$ & .000 \\
\hline & Pearson Correlation & 329 & \\
\hline & Sig. (2-tailed) & & 1 \\
\hline & $\mathrm{N}$ & & \\
\hline
\end{tabular}

Source: Field data, (2018). $* *$ Correlation is significant at the 0.01 level (2-tailed)

Findings reveal a significant relationship between individual offender characteristics and recidivism among released inmates in Kakamega County $(\mathrm{r}=0.669 ; \mathrm{P}<0.01)$, implying that individual characteristics significantly influence repeat offending among released inmates. The null hypothesis is rejected at the level of significance of 0.01 and its alternative is adopted, stating a significant relationship between individual characteristics and recidivism among released inmates.

To determine the differences in the extent of the influence of individual characteristics on recidivism, findings on measures of dispersion and variability are presented in Table 6.

Table 6: Individual characteristics and their influence on recidivism

\begin{tabular}{|l|r|r|r|}
\hline Influence type & Mean & \multicolumn{1}{|l|}{ Standard Deviation } & Standard Error of Mean \\
\hline Gender & 1.39 & .3591 & .04541 \\
\hline Age & 1.37 & .3671 & .04356 \\
\hline Offence type & 1.31 & .3743 & .04691 \\
\hline Number of convictions & 1.04 & .3975 & .04591 \\
\hline Period between incarcerations & 1.02 & .4167 & .03444 \\
\hline Type of prison sentence & 1.18 & .4322 & .03549 \\
\hline Drug use prior to incarceration & 1.27 & .4191 & .03298 \\
\hline
\end{tabular}

Source: Field data, (2018)

Information in Table 6 reveal that the mean for gender is the highest (1.39), implying that gender is the individual characteristic with the highest influence on recidivism. There are significantly more male recidivists (compared to incarcerated male offenders) than female recidivists (compared to incarcerated female offenders).

Age has the second-highest influence on recidivism with a mean of 1.37. This also reflects the age differences among recidivists, since there are more youthful offenders in prison as compared to aged or older offenders.

Offence type has a mean of 1.31 which points to the influence of offence type to recidivism. Property offences are more prevalent among sampled recidivists as compared to violent offences.

Drug and substance use (prior to incarceration) has a mean of 1.27 implying that even though there are recidivists who have committed offences related to drug and substance abuse, the rate of recidivism in this category of offence is not prevalent.

Prison sentence as long, medium or short has a mean of 1.18, implying that the length of a previous prison sentence has minimal influence on recidivism.

Given the small differences in the means for the various individual characteristics in explaining recidivism, we need to establish whether these differences in the means are statistically significant. In this regard, a onesample independent t-test for equality of means has been computed at 0.05 level of significance and findings presented in Table 7.

Table 7: T-Test for equality of means

\begin{tabular}{|l|r|r|r|r|r|r|r|}
\hline & \multicolumn{2}{|l|}{$\begin{array}{l}\text { Levene's Test for } \\
\text { Equality of Variances }\end{array}$} & \multicolumn{2}{|l|}{ t-test for Equality of Means } \\
\hline & $\mathrm{F}$ & Sig. & $\mathrm{T}$ & $\mathrm{df}$ & $\begin{array}{c}\text { Sig. (2- } \\
\text { tailed) }\end{array}$ & $\begin{array}{c}\text { Mean } \\
\text { Difference }\end{array}$ & $\begin{array}{c}\text { Std Error } \\
\text { Difference }\end{array}$ \\
\hline Equal variances assumed & 0.371 & .508 & 3.308 & 28 & .027 & 2.945 & 1.374 \\
\hline $\begin{array}{l}\text { Equal variances not } \\
\text { assumed }\end{array}$ & & & 3.009 & 27.417 & .042 & 3.071 & 1.399 \\
\hline
\end{tabular}

Source: Field data, (2018). $t$-critical $(d f=2,28, t=2.99, p \leq 0.05) ;$-calculated $(d f=2,28, t=3.308, p=0.027)$ 
There is a statistically significant difference in the mean between the individual characteristics as indicators of recidivism among released inmates in Kakamega County $(\mathrm{t}=3.308, \mathrm{P}<0.05, \mathrm{df}=2,28)$. This is further illustrated where the critical t-value (2.99) is less than the calculated t-value (3.308).

Regression analysis of offender characteristics and recidivism

Research data on offender characteristics has been subjected to regression analysis to predict recidivism amongst released offenders within Kakamega County. Findings appear in Table 8.

Table 8: Model summary for offender characteristics and recidivism

\begin{tabular}{|r|r|r|r|r|r|}
\hline Model & R & R Square & $\begin{array}{c}\text { Adjusted R } \\
\text { Square }\end{array}$ & Std. Error of the Estimate & \multicolumn{1}{c|}{ Durbin-Watson } \\
\hline 1 & $.478^{\mathrm{a}}$ & .237 & .234 & .78652 & 1.775 \\
\hline
\end{tabular}

Source: Research data, (2018). a) Constant Predictors: Offender Characteristics; Dependent variable: Recidivism

Findings from the regression analysis where offender characteristics are used as predictors of recidivism reveal an $\mathrm{R}$ squared value of 0.237 implying that offender characteristics account for $23.7 \%$ of the variance in recidivism among sampled offenders.

ANOVA results for offender characteristics and recidivism

An analysis of variance (ANOVA) is computed for the relationship between offender characteristics and recidivism and findings presented in Table 9.

Table 9: ANOVA for offender characteristics and recidivism

\begin{tabular}{|l|l|r|r|r|r|r|}
\hline \multicolumn{2}{|c|}{ Model } & Sum of Squares & Df & Mean Square & \multicolumn{1}{c|}{ F } & Sig. \\
\hline \multirow{2}{*}{1} & Regression & 59.431 & 1 & 48.655 & 69.771 & $.000^{\mathrm{a}}$ \\
\cline { 2 - 7 } & Residual & 191.793 & 327 & .584 & & \\
\cline { 2 - 7 } & Total & 251.224 & 328 & & & \\
\hline
\end{tabular}

Source: Research data, (2018). a) Constant Predictors: Offender Characteristics; b) Dependent Variable: Recidivism

Findings (Table 9) reveal an $\mathrm{F}$ value of 69.771 , which is highly significant with a p-value $=0.000$. This implies that the study model is a good predictor of the association between offender characteristics and recidivism.

Coefficients for offender characteristics and recidivism

The coefficients for offender characteristics and recidivism are presented in Table 10.

Table 10: Coefficient for offender characteristics and recidivism

\begin{tabular}{|c|c|c|c|c|c|c|c|}
\hline \multirow[b]{2}{*}{ Model } & \multicolumn{2}{|c|}{$\begin{array}{l}\text { Unstandardised } \\
\text { Coefficients }\end{array}$} & \multirow{2}{*}{\begin{tabular}{|c|} 
Standardised \\
Coefficients
\end{tabular}} & \multirow[b]{2}{*}{$\mathbf{T}$} & \multirow[b]{2}{*}{ Sig. } & \multicolumn{2}{|c|}{ Collinearity Statistics } \\
\hline & $\mathrm{B}$ & Std. Error & & & & Tolerance & VIF \\
\hline (Constant) & .671 & .107 & & 4.866 & .000 & & \\
\hline Environment & .492 & .043 & .447 & 6.319 & .000 & 1.000 & 1.00 \\
\hline
\end{tabular}

Source: Research data, (2018). Dependent Variable: Recidivism

Multi-collinearity is measured by the Variance Inflation Factor (VIF). Where the VIF exceeds 10, independent variables are highly correlated amongst themselves, leading to a multi-collinearity problem (where the change in the dependent variable cannot certainly be attributed to the independent variables). The VIF value in Table $10(\mathrm{VIF}=1)$ is less than 10 , so there is no multi-collinearity problem. Analysis of the regression model coefficients shows a beta coefficient of 0.492 for offender characteristics with a P-value $=0.000$, implying a significant relationship between offender characteristics and the dependent variable (recidivism).

\subsection{QUALITATIVE ANALYSIS OF OFFENDER CHARACTERISTICS AND RECIDIVISM}

In this discussion findings from interviews and focus-group interviews are presented. From the responses it is evident that individual offender characteristics significantly influence recidivism among released inmates.

Interviews with probation and prison officers

The opinions of probation officers and prison officers on the relationship between offender characteristics and recidivism were obtained. The aim is to assess whether the characteristics exhibited by offenders would explain the possibility of repeat offending. The majority of the interviewed probation officers $(69.4 \%)$ were of the view that offender characteristics have a significant influence on recidivism among released inmates in Kakamega County.

Probation officers largely (57.1\%) indicate that youthful offenders are more likely to breach probation orders, compared to older offenders. Probation officers indicate that male offenders are highly likely to breach probation order conditions, compared to females. When offenders breach probation orders they get arrested and receive alternative sentences, making them repeat offenders. In 2017, Kenya had 16371 male recidivists (from around 52000 male inmates) and 1453 female recidivists (from around 5000 female inmates) (Kenya National 
Bureau of Statistics, 2018: 267).

Probation officers $(52.9 \%)$ indicate that the offence type significantly influence recidivism. Interviewed officers observe that offenders who have committed crimes of a utilitarian nature (theft, burglary, etc.) are more likely to repeat similar or more severe offences. This corroborates statistics from the Kenya Economic Survey (2018: 270)

Interviewed prison officers $(72.3 \%)$ indicate that sentenced petty offenders are more likely to recidivate due to the nature of short sentences that they receive (ranging from one week to six months). During short sentences offenders do not undergo any tangible rehabilitation. Also, drug-related offenders, or those with a narcotic drug use history were more likely to become repeat offenders due to negative influences and drug related peer group associations.

\section{Focus group interviews with families and community members}

Focus group interviews were conducted with families of recidivist and community members to gain insights into how placement on probation after incarceration affects the offender's life and character.

Interview results allude to mixed findings. Some participants $(47.1 \%)$ opine that offenders have improved in character since incarceration. Others $(50.2 \%)$ indicate that offender characters have worsened. A minority $(2.7 \%)$ feel there was no significant change in the character of offenders before and after incarceration or placement on probation. Some responses are shared below.

The mother of an offender:

"My son has significantly improved his behaviour. He is helpful at home and relates well with his siblings contrary to what the case was before his imprisonment” Murhanda village (14/6/2018).

A local administrator in Murhanda, Kakamega East Sub-County:

"We have keenly observed the offender since his release. There is not much difference in his behaviour. He still keeps the bad company of known criminals and is suspected of smoking outlawed substances. Based on his behaviour, my assistant chiefs suspect him of involvement in the increased criminal activities in this location" Murhanda Location (14/6/2018).

Family members were requested to comment on how the offender relates to them, other relatives, neighbours, and community members. Family members had mixed feelings when asked if the offenders were supportive of the immediate family. Some family report that offenders are supportive of immediate family members and were more responsible. Others argue that offenders have neglected their spouses and children, and were more into negative social groups.

A mother of an offender from Lihovero, Khayega reported as follows about how supportive her son was after placement on parole:

"My son has reduced alcohol consumption and loitering and is more supportive of his wife and children. He works hard to secure casual work. The wife is happier than before and they eat well nowadays" Khayega Location (20/6/2018).

Focus group discussions with two ex-offenders, four family members of an ex-offender, a crime victim, four community and local administration members, and a religious leader present mixed feelings regarding the potential of offenders to engage in repeat offending. Family members were optimistic that ex-offenders would eventually change. Community members and local administrators have divergent views regarding the possibility of ex-offenders reforming after a period of incarceration. A sibling to a released inmate in Munyuki, Lugari SubCounty reacted as follows when asked if his sister would stop selling unlicensed alcohol:

"She has been selling illicit brew all her adult life, but she has desisted from it for the last five months [during parole]. The probation officer warned her not to sell. She recently received a tailoring machine and start-up capital from the State. She does tailoring within Munyuki Market to feed her family" Munyuki Village $(16 / 6 / 2018)$

A community member in Sayangwe, Matungu Sub-County reported as follows on the possibility of offenders returning to repeat offending:

"Most offenders from this area charged for stealing and possession of narcotic drugs are jailbirds. They are in and out of prison. It would be quite surprising for most of them to finish a whole year before being arrested" Sayangwe (15/6/2018).

A local administrator at Marenyo Chief's Camp reacted as follows to the same question:

"Petty crime offenders come back from prison as hardened criminals and give us sleepless nights. They commit more serious crimes. One offender recently attempted to rob a bar in Butere. He has gone missing and efforts are underway to apprehend him" Marenyo Village (21/6/2018).

Inasmuch as close relatives to recidivists might want to portray offenders as being capable of becoming good citizens, community members mostly hold opposing views. Recidivists are to be suspected when there is nobody else in the community to suspect. 


\subsection{RELATIONSHIP BETWEEN OFFENDER REINTEGRATION AND RECIDIVISM}

The qualitative and quantitative analysis of the nexus between offender reintegration and recidivism will now be discussed.

\subsubsection{QUANTITATIVE ANALYSIS ON OFFENDER REINTEGRATION AND RECIDIVISM}

The second specific objective seeks to interrogate the relationship between offender reintegration and recidivism. It aims to understand how prison rehabilitation programmes, post-release community reception of offenders, post-release social support structures, and social interactions after release influence the likelihood of recidivism. The following hypotheses guide the objective:

Ho2: Offender reintegration has no significant influence on recidivism

$\mathrm{H}_{12}$ : Offender reintegration has a significant influence on recidivism

Data relating to community reintegration and to recidivism are subjected to various descriptive and inferential statistics. The Pearson Product Moment Correlation Coefficient is performed between offender reintegration and recidivism among released inmates in Kakamega County. Findings are presented in Table 11.

Table 11: Relationship between offender reintegration and recidivism

\begin{tabular}{|l|l|r|c|}
\hline & & Offender Reintegration & Recidivism \\
\hline Offender Reintegration & Pearson Correlation & 1 & \\
\hline & Sig. (2-tailed) & 329 & \\
\hline & $\mathrm{N}$ & $.541\left(^{* *}\right)$ & .000 \\
\hline & Pearson Correlation & 329 & 1 \\
\hline & Sig. (2-tailed) & Necidivism & N \\
\hline
\end{tabular}

Source: Field data, (2018). ${ }^{* *}$ Correlation is significant at the 0.01 level (2-tailed).

Findings in Table 11 reveal a significant relationship between offender reintegration and recidivism among released inmates $(\mathrm{r}=0.541 ; \mathrm{P}<0.01)$. This implies that rehabilitation programmes in prison, community reception of offenders upon release, post-release social support structures and social interactions of offenders after release, the possibility of securing a job after release and availability and access to support from faith-based organisations influence the likelihood of recidivism among inmates in Kakamega County. The statistically significant relationship between offender reintegration and recidivism at the level of significance of 0.01 means the null hypothesis is rejected and its alternative adopted.

The direction and magnitude of the influence of the various study constructs for offender reintegration used in the study is determined by subjecting the data to multivariate regression analysis. Findings are presented in Table 12.

Table 12: Multiple regression results for offender reintegration on recidivism

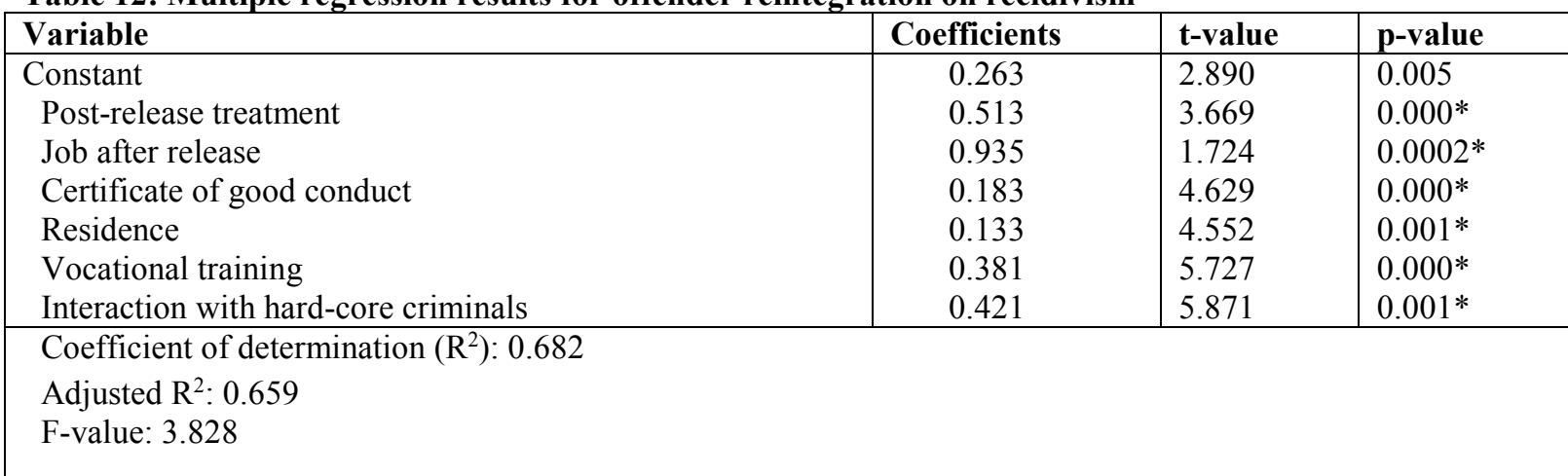

\section{Source: Field data, (2018)}

Findings above show multiple regression results for offender reintegration factors as predictors of recidivism. Calculated t-statistics for the following parameters are greater than tabulated t-statistics at 0.05 level of significance: post-release treatment, ability to secure a job after release, access and use of certificate of good conduct, residence after release, vocational training during incarceration, and interaction with hard-core criminals during incarceration. Therefore, all six constructs have a significant influence on recidivism (with $\mathrm{p}$ values less than 0.05 ).

The coefficient of determination $\left(\mathrm{R}^{2}\right)$ is 0.682 , meaning the six constructs account for $68.2 \%$ of variation in recidivism among released persons in Kakamega County. The remaining 38.1\% unknown parameter is ascribed to variance outside of the regression. The cumulative regression method is statistically significant $(\mathrm{f}=3.867$, $\mathrm{P}<0.05$ ).

Data for offender reintegration appear in Table 13. 
Table 13: Frequency distribution for reintegration factors

\begin{tabular}{|c|c|c|c|}
\hline \multirow[b]{2}{*}{ Variable } & Total & Male & Female \\
\hline & $(\mathrm{N}=329)$ & $(\mathrm{N}=298)$ & $(\mathrm{N}=31)$ \\
\hline \multicolumn{4}{|c|}{ Participation in post-release treatment } \\
\hline Yes & $79.2 \%$ & $53.5 \%$ & $25.7 \%$ \\
\hline No & $13.9 \%$ & $9.7 \%$ & $4.2 \%$ \\
\hline \multicolumn{4}{|l|}{ Employment after release } \\
\hline Yes & $29.1 \%$ & $19.8 \%$ & $9.3 \%$ \\
\hline No & $63.7 \%$ & $48.5 \%$ & $15.2 \%$ \\
\hline \multicolumn{4}{|l|}{ How employment was secured } \\
\hline Through friends & $39.8 \%$ & $27.9 \%$ & $11.9 \%$ \\
\hline Through family & $27.4 \%$ & $18.3 \%$ & $9.1 \%$ \\
\hline Programmes assisting ex-offenders & $3.2 \%$ & $1.9 \%$ & $1.3 \%$ \\
\hline Personal efforts & $18.9 \%$ & $13.1 \%$ & $5.8 \%$ \\
\hline \multicolumn{4}{|c|}{ Whether police clearance was necessary } \\
\hline Yes & $23.5 \%$ & $22.3 \%$ & $1.2 \%$ \\
\hline No & $69.3 \%$ & $57.1 \%$ & $12.2 \%$ \\
\hline \multicolumn{4}{|l|}{ Type of employment } \\
\hline Formal job in government & $17.4 \%$ & $13.5 \%$ & $3.9 \%$ \\
\hline Formal job in private sector & $63.7 \%$ & $49.1 \%$ & $14.6 \%$ \\
\hline Other & $9.1 \%$ & $7.7 \%$ & $1.4 \%$ \\
\hline
\end{tabular}

Source: Field data, (2018). Sample size varies due to missing values

Data in Table 13 reveal that $79.2 \%$ of respondents report receiving post-release treatment. Only $29.1 \%$ could secure employment immediately upon release. The majority of respondents $(39.8 \%)$ secure employment through friends. Only 3.2\% could secure employment through offender-release programmes. Reasons for this low outcome need further research. Nearly $70 \%$ of respondents did not need certificates of good conduct in securing jobs. Regarding the type of employment, the modal response category is formal private sector employment (63.7\%).

Respondents were requested to state the kind of reintegration treatment received in prison. Details occur in Table 14.

Table 14: Frequency distribution for reintegration factors

\begin{tabular}{|c|c|c|c|}
\hline \multirow[t]{2}{*}{ (a } & Total & Male & Female \\
\hline & $(\mathrm{N}=329)$ & $(\mathrm{N}=298)$ & $(\mathrm{N}=31)$ \\
\hline \multicolumn{4}{|l|}{ Type of treatment received } \\
\hline Substance abuse & $5.2 \%$ & $4.8 \%$ & $0.4 \%$ \\
\hline Sex offender & $21.7 \%$ & $18.3 \%$ & $3.4 \%$ \\
\hline Anger management & $19.5 \%$ & $12.7 \%$ & $6.8 \%$ \\
\hline Formal education & $33.3 \%$ & $21.4 \%$ & $11.9 \%$ \\
\hline Vocational training & $17.9 \%$ & $9.1 \%$ & $8.8 \%$ \\
\hline \multicolumn{4}{|l|}{ Importance of treatment in prison } \\
\hline Strongly agree & $28.8 \%$ & $16.5 \%$ & $12.3 \%$ \\
\hline Agree & $23.5 \%$ & $14.9 \%$ & $8.6 \%$ \\
\hline Neutral & $16.9 \%$ & $10.1 \%$ & $6.8 \%$ \\
\hline Disagree & $19.5 \%$ & $13.9 \%$ & $5.6 \%$ \\
\hline Strongly disagree & $6.7 \%$ & $4.9 \%$ & $1.8 \%$ \\
\hline \multicolumn{4}{|c|}{ Whether currently undertaking treatment } \\
\hline Yes & $69.1 \%$ & $48.9 \%$ & $20.2 \%$ \\
\hline No & $28.3 \%$ & $19.5 \%$ & $8.8 \%$ \\
\hline
\end{tabular}

Source: Field data, (2018). Data weighted by gender. Sample size varies due to missing values.

With regard to the type of prison treatment received, data reveals a modal response category of formal education with $33.3 \%$. This points to the willingness of offenders to learn and change their ways given the opportunity. A significant number of offenders (28.8\%) strongly agree that offender treatment is important, while $69.1 \%$ were undergoing current treatment. An alarmingly high number still received no treatment during incarceration.

Respondents were asked whether they had contact with hard-core criminals during incarceration, whether it would hinder effective reintegration, and whether there were any facilitated linkages for family and community interaction with imprisoned offenders before release. Statistics appear in Table 15. 
Table 15: Frequency distribution for reintegration factors

\begin{tabular}{|c|c|c|c|}
\hline \multirow[b]{2}{*}{ Variable } & Total & Male & Female \\
\hline & $(\mathrm{N}=329)$ & $(\mathrm{N}=298)$ & $(\mathrm{N}=31)$ \\
\hline \multicolumn{4}{|l|}{ Interaction with hard-core criminals } \\
\hline Yes & $71.9 \%$ & $5.9 \%$ & $1.5 \%$ \\
\hline No & $19.6 \%$ & $8.3 \%$ & $3.1 \%$ \\
\hline \multicolumn{4}{|c|}{ Whether interaction increased reoffending chances } \\
\hline Strongly agree & $37.1 \%$ & $26.3 \%$ & $10.8 \%$ \\
\hline Agree & $27.5 \%$ & $17.8 \%$ & $9.7 \%$ \\
\hline Neutral & $14.1 \%$ & $9.3 \%$ & $3.8 \%$ \\
\hline Disagree & $11.1 \%$ & $7.5 \%$ & $3.6 \%$ \\
\hline Strongly disagree & $8.9 \%$ & $6.4 \%$ & $2.5 \%$ \\
\hline \multicolumn{4}{|l|}{ Involvement in re-entry programmes } \\
\hline Yes & $13.5 \%$ & $8.9 \%$ & $4.6 \%$ \\
\hline No & $74.1 \%$ & $58.2 \%$ & $15.9 \%$ \\
\hline \multicolumn{4}{|c|}{ Programmes involve family and community } \\
\hline Strongly agree & $32.8 \%$ & $19.1 \%$ & $13.7 \%$ \\
\hline Agree & $30.9 \%$ & $22.8 \%$ & $8.1 \%$ \\
\hline Neutral & $13.1 \%$ & $9.3 \%$ & $3.8 \%$ \\
\hline Disagree & $11.9 \%$ & $8.7 \%$ & $3.2 \%$ \\
\hline Strongly Disagree & $9.8 \%$ & $6.4 \%$ & $3.4 \%$ \\
\hline
\end{tabular}

Source: Field data, (2018). Data weighted by gender. Sample size varies for select variables due to missing values.

Findings reveal that $71.9 \%$ of respondents interact with hard-core criminals during incarceration. Of these, $37.1 \%$ strongly agree that such interaction increase their recidivism risk. Most respondents are aware that contact with hard-core criminals has relation to recidivism.

In total, $74.1 \%$ of respondents reveal that they were not involved in re-entry programmes with family and community members. However, $32.8 \%$ strongly agree that such re-entry programmes are important for successful reintegration. Re-entry programmes foster reconciliation, reintegration, and restitution between offenders, the victims and communities.

\subsection{QUALITATIVE ANALYSIS FOR OFFENDER REINTEGRATION AND RECIDIVISM}

We now discuss findings from interviews conducted with probation and prison officers, and focus group discussions with ex-offender families, victim representatives, community members, local administration, and religious leaders.

Interviews with probation and prison officers

Probation and prison officers provided information regarding the nexus between offender reintegration and repeat offending among released inmates in Kakamega County, Kenya. Findings reveal that the majority of probation officers $(81.05 \%)$ opine that offenders who adhered to scheduled rehabilitation plans were less likely to recidivate, compared to those not following rehabilitation plans.

Interviews (seven probation officers at Kakamega Central Sub-County, five probation officers at Mumias Probation Office) unveil that minor offences (housebreaking, simple assault, theft) qualify for community sentences. Offences punishable to three years imprisonment or less can be committed into community sentences (Probation Orders and Community Service Orders). These orders are imposed by Criminal Courts (Republic of Kenya, 2012b: 5).

For probation sentences, probation officers compile treatment plans to assist offenders with rehabilitation. Probation officers mostly use evidence-based treatment techniques, including motivational interviewing and cognitive behavioural therapy (Obondi, 2017: 68). A probation sentence requires that offenders report to probation officers regularly, depending on needs and risk analysis.

Community Service Orders (CSO) are sentences imposed by Criminal Courts to offenders deemed noninjurious to the community (Republic of Kenya, 1998: 3). These offenders who would have been incarcerated for less than three years. Offenders under CSO must adhere to prescribed conditions. They can be incarcerated should they violate their conditions. The CSO Programme is mandated through the Community Service Orders Act. Offenders under CSO must perform unpaid public service work, a form of retribution and payback to the offended community. Examples of public work include digging pit latrines at schools; cleaning of market places, schools, dispensaries, and public places; and maintaining rural access roads.

During CSO periods, probation officers compile offender rehabilitation plans with the objective to avoid reoffending. They organise reconciliation sessions between offenders, their families, and victim families before the 
release of offenders back into the community. It prepares offenders and victims for re-entry activities. Offender families are a potential source of support and assistance upon community re-entry, but is often lacking.

The social control theory postulates that crime reduction is an outcome of family attachment (Hirschi, 1969: 44). Attachment to parents reduces the likelihood of antisocial behaviour. Social support reduces recidivism (Berg \& Huebner, 2011: 191; Visher \& Travis, 2003: 29). According to Berg and Huebner (2011: 39) family social ties reduce criminal behaviour.

Prison officers report that incarcerated offenders who complete training in skilled craft are less likely to reoffend (Kimani, 2016: 86). Interviews with prison officers unveil that the chaplaincy office spearheads counselling sessions. Spiritual rehabilitation is quite active in all prisons in Kakamega County. External religious organisations assist with spiritual empowerment. Most inmates respond positively and are less likely to engage in repeat offending.

As a strategy to reduce the negative influence between incarcerated hard-core criminals and petty offenders, different categories of offenders are incarcerated in different accommodation units. Hard-core criminals and petty offenders are separated. According to interviews with prison officers, there are three categories of offenders in prison are separated as follows:

- Capital offenders - offenders who committed offences punishable by death or life sentences (murder, robbery with violence, treason);

- Inmates sentenced to more than ten years - sexual offenders, those convicted for causing grievous bodily harm, arson, possession of firearms and ammunition, and attempted suicide; and,

- Inmates convicted for petty offences - affray, assault, traffic offences, stealing, burglary, forest-related offences, and other misdemeanours.

Prison officers at Shikusa Prison, Kakamega Main Prison and Kakamega Women Prison note that in some instances (during meals, sports, entertainment, etc.) inmates interact freely. Such interaction provide opportunities to exchange negative values.

\section{Focus group interview results}

Focus group discussions with ex-offender families, victim families, community members, local administration, and religious leaders were conducted to determine whether offenders had been assisted in the reintegration process. Post-release interventions should support the immediate transition from incarceration to reintegration and continue throughout reintegration (Fox, 2002: 123).

The majority of the family $(67.5 \%)$ and community members $(59.1 \%)$ maintain that most ex-offenders were not provided with tools and support to facilitate resettlement. There are exceptional cases where ex-offenders had received support directly from the State or from non-governmental organisations, like Ahadi Trust and Rodi Kenya. One offender from Musoli who served twenty years imprisonment at Kakamega G.K Prison, reports as follows:

"I was sentenced to twenty years imprisonment for manslaughter. After fourteen years, the Power of Mercy Advisory Committee requested for a report from Probation Officers. The officers interviewed me and recommended that I be released, since I was remorseful and circumstances at home had changed. In prison I had training in carpentry and was issued with a competence certificate. Probation officers recommended me and linked me to Ahadi Trust who issued me with a free carpentry toolkit, rented a workshop at Musoli Market and paid six months' rent. They bought timber and five hundred tokens of electricity. I am now settled and will be able to educate my children, and never go back to crime again” Musoli Sub-location (24/6/2018).

A female respondent from Emutetemo had been previously incarcerated for six months for brewing illicit liquor. She was re-arrested two months after her release for selling illicit brew and placed under six months community service. She reports as follows regarding provision of tools or equipment after release:

"I was not given tools since I did not have any prior training or skills. Only those who were trained in some trades were considered for empowerment. We were called to the probation office during their open day and the NGO Rodi Kenya trained us to make liquid detergents and Shampoo. We were not given any capital to start off. If I get money I will try to make liquid detergents and supply to schools and dispensaries around my community to legitimately earn some money” Emutetemo village (27/6/2018).

Some released offenders are fully supported, while others were partially empowered. Those offenders who serve short sentences do not undergo significant rehabilitation and they do not receive support. This increases their recidivism risk.

On whether offenders had sought or secured any gainful employment after release from prison, respondents had mixed reactions. The family of an offender from Shivagala Village who served six months at Shikusa Prison reacted as follows when asked if the offender had sought or secured employment:

"Has no time to look for work, just roams the village. People suspect that he still engages in criminal activities... he spends time gambling, drinking, smoking bhang and seducing old women ...it will not be surprising find that he has been re-arrested again" Shivagala village (28/6/2018).

A village elder of Shikoho said this about his neighbour who had been imprisoned for twelve months at 
Shikusa Prison:

"That boy has been working at a construction site at Shikoho Secondary School. He has been undertaking work on a Constituency Development Fund project for three months. He receives three hundred and fifty shillings everyday... he reformed and we have never heard that he is involved in any bad company, he attends church service every Sunday where he testifies that he has changed,...the boy is reformed" Shikoho village (28/6/2018).

Employment opportunities lower involvement in criminal behaviour (Mackenzie, 2006: 81; Sampson \& Laub, 2003: 19). Desistance depends critically on employment, specifically finding and holding employment (Bushway \& Reuter, 2002: 36). Obtaining legal employment is one of the best predictors of the post-release success of offenders (Visher, Sara, Sherril \& Haner, 2005: 699).

Focus group interview results about skills gained in prison are mixed. Some respondents state that offending relatives had not gained any skills. Others indicate that relatives were trained in various skills, including painting, electrical wiring, masonry, and others. Long-term inmates benefit more than short-term inmates. The majority of those who completed vocational training were applying their skills to earn a living.

\subsection{INFLUENCE OF THE COMMUNITY PERCEPTION AND ATTITUDE ON RECIDIVISM}

The third objective investigates the influence of community perception on recidivism among released inmates in Kakamega County. Of interest are the reception by families and the community after release; family visits while incarcerated; social interactions after release; perceptions of the influence of communities on recidivism; financial and material support during release; a family history of convictions; influences of neighbourhoods on reoffending; and support from faith-based organisations after release. Research data relating to community perception and that relating to recidivism are subjected to various descriptive and inferential statistics and findings presented in the next section. The following hypotheses guide the objective:

$\mathrm{H}_{0}$ 3: Community perception and attitude do not significantly influence recidivism

$\mathrm{H}_{1}$ 3: Community perception and attitude has a significant influence on recidivism

\subsubsection{QUANTITATIVE ANALYSIS OF COMMUNITY PERCEPTION AND ATTITUDE ON RECIDIVISM}

The relationship between community perception and recidivism is subjected to Pearson product-moment Correlation Coefficient. Findings are presented in Table 16.

Table 16: Relationship between community perception and recidivism

\begin{tabular}{|l|l|r|r|}
\hline & & Community Perception & Recidivism \\
\hline Community Perception & Pearson Correlation & 1 & \\
\hline & Sig. (2-tailed) & 329 & \\
\hline & $\mathrm{N}$ & $.565\left(^{*}\right)$ & .015 \\
\hline & Pearson Correlation & 329 & 1 \\
\hline & Sig. (2-tailed) & $\mathrm{N}$ & \\
\hline
\end{tabular}

Source: Field data, (2018) *Correlation is significant at the 0.05 level (2-tailed).

Findings in Table 16 reveal a significant relationship between community perception and recidivism among released inmates in Kakamega County $(\mathrm{r}=0.565 ; \mathrm{P}<0.05)$. Community perceptions and attitudes towards offenders have a significant influence on potential recidivism. Perceptions of exclusion, ridicule, and stigmatisation may influence offenders to become defensive and develop antisocial personalities that might encourage recidivism. This confirms findings from interactions with some inmates at Shikusa Prison who indicate that they prefer to stay in prison, as they are regarded as social misfits in society. Therefore, they will commit offences to return to prison.

The study found a significant relationship between community perception and recidivism among released inmates (level of significance of 0.05). The null hypothesis is rejected and its alternative (community perception and attitude have a significant influence on recidivism) is confirmed.

To investigate the direction and magnitude of influence of the study constructs on community perception on recidivism, study data is subjected to multivariate regression analysis and findings presented in Table 17. 
Table 17: Multiple regression results for community perception and recidivism

\begin{tabular}{|c|c|c|c|}
\hline Variable & Coefficients & t-value & p-value \\
\hline Constant & 0.362 & 2.541 & 0.003 \\
\hline Family reception & 0.469 & 4.158 & 0.001 \\
\hline Family visits in prisons & 0.437 & 3.503 & 0.001 \\
\hline Community reception & 0.471 & 3.391 & 0.000 \\
\hline Social interactions & 0.532 & 3.664 & 0.001 \\
\hline Labelling and tagging & 0.394 & 4.296 & 0.002 \\
\hline
\end{tabular}

Source: Field data, (2018)

Findings in Table 17 reveal multiple regression analysis results for community perception and attitude as recidivism predictors. The constructs investigated are family reception, family visits in prison, community reception upon release, social interactions, and offender labelling. Findings reveal that calculated $\mathrm{t}$-statistics $(\mathrm{t}=$ $4.158,3.503,3.391,3.664$ and 4.296) for the parameters family reception, family visits in prison, community reception upon release, social interactions, and offender labelling respectively are greater than tabulated $\mathrm{t}$ statistics at 0.05 significance level. All five constructs have a significant influence on recidivism (all p-values were less than 0.05 ).

The coefficient of determination $\left(\mathrm{R}^{2}\right)$ is 0.557 , implying that family reception, family visits in prison, community reception upon release, social interactions and offender labelling accounted for $55.7 \%$ of the variation in recidivism. The remaining $44.3 \%$ variable is largely due to variation in other factors influencing recidivism, which are outside the regression model and which are otherwise included in the stochastic error term. The overall regression model is statistically significant in terms of its overall goodness of fit $(\mathrm{f}=4.161, \mathrm{P}<0.05)$. A descriptive analysis of community perception constructs and their influence on recidivism is done and findings presented in Table 18.

Table 18: Frequency distributions for community perception factors

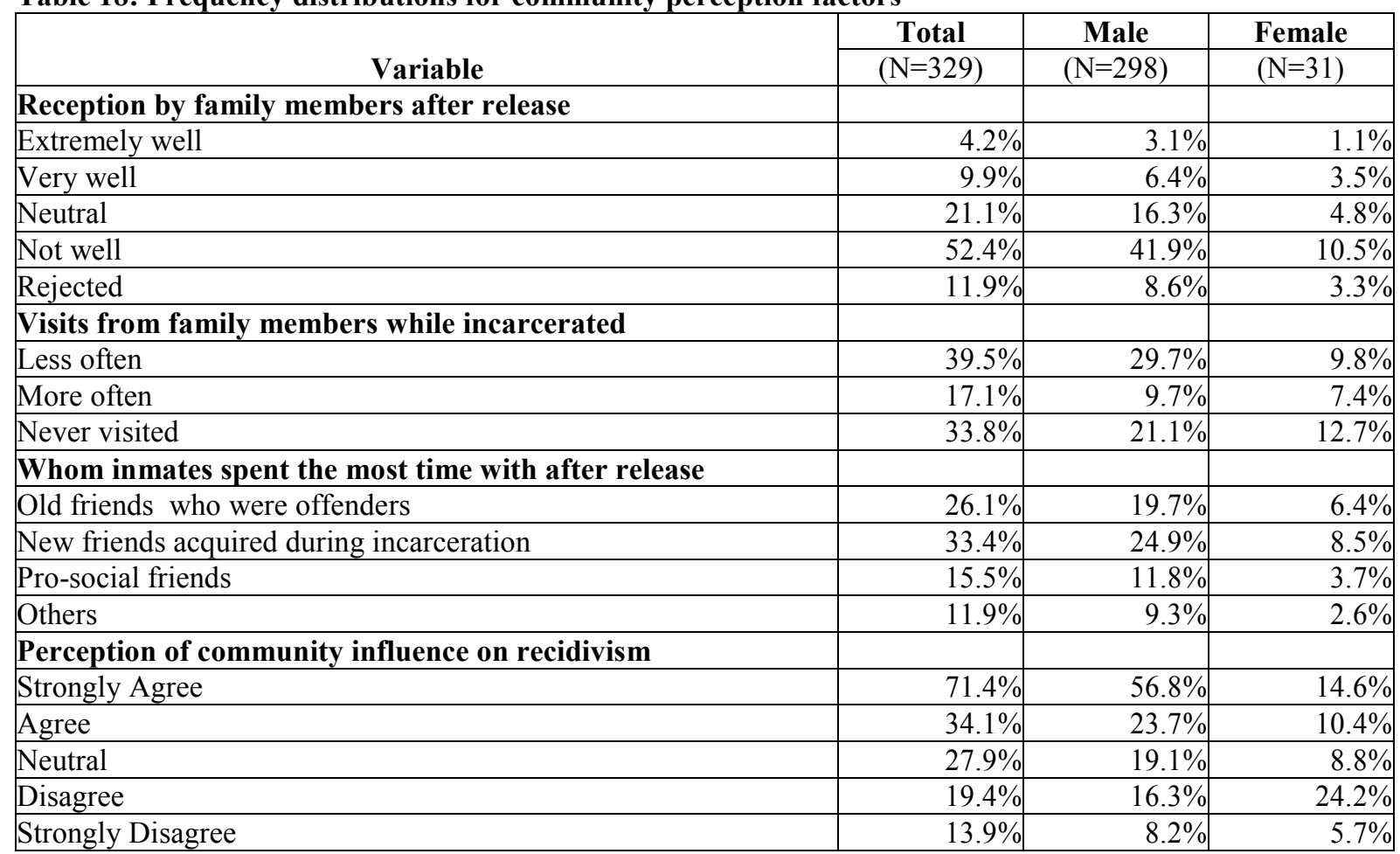

Source: Field data, (2018). Data are weighted by gender. The sample size varies for select variables due to missing values.

Most respondents argue that they were not received well by family (52.4\%), revealing a relationship between family rejection and recidivism among released inmates in Kakamega County. When asked about family visits during incarceration, the modal response category was "less often" (39.5\%) followed by "never visited" $(33.8 \%)$.

The study reveals that, after release, most respondents spent significant time with new friends acquired while incarcerated $(33.4 \%)$, followed by old offender friends $(26.1 \%)$. This implies that the potential negative peer influence arising from association with offenders may lead to recidivism. This notion is supported by empirical studies on recidivism (Lievore, 2004: 60; Benda 2005: 233; Scott, 2004: 342). 
Respondents were asked if they agreed that communities influence ex-offenders to re-offend through tagging and labelling, where $71.4 \%$ "strongly agree." A significant number of respondents strongly believe that community labelling and tagging have detrimental influences on the likelihood of re-offending.

A descriptive analysis was conducted to determine how offenders receive material and financial support (and related matters listed below) upon release. Findings appear in Table 19.

Table 19: Frequency distributions for community perception factors

\begin{tabular}{|c|c|c|c|}
\hline \multirow[b]{2}{*}{ Variable } & Total & Male & Female \\
\hline & $(\mathrm{N}=329)$ & $(\mathrm{N}=298)$ & $(\mathrm{N}=31)$ \\
\hline \multicolumn{4}{|c|}{ How material and financial support was secured } \\
\hline Family members & $8.5 \%$ & $5.9 \%$ & $2.6 \%$ \\
\hline Relatives & $24.9 \%$ & $17.6 \%$ & $7.3 \%$ \\
\hline Friends & $45.4 \%$ & $37.6 \%$ & $7.8 \%$ \\
\hline Programmes for assisting ex-offenders & $3.9 \%$ & $2.1 \%$ & $1.8 \%$ \\
\hline Others & $11.4 \%$ & $7.9 \%$ & $3.5 \%$ \\
\hline \multicolumn{4}{|l|}{ Previous convicts in the family } \\
\hline Yes & $59.8 \%$ & $49.9 \%$ & $9.9 \%$ \\
\hline No & $33.5 \%$ & $24.1 \%$ & $9.4 \%$ \\
\hline \multicolumn{4}{|c|}{ Influence of neighbourhood on reoffending } \\
\hline Strongly agree & $35.1 \%$ & $21.8 \%$ & $13.3 \%$ \\
\hline Agree & $24.4 \%$ & $18.7 \%$ & $5.7 \%$ \\
\hline Neutral & $9.8 \%$ & $5.7 \%$ & $4.1 \%$ \\
\hline Disagree & $10.3 \%$ & $6.5 \%$ & $3.8 \%$ \\
\hline Strongly disagree & $8.2 \%$ & $5.1 \%$ & $3.1 \%$ \\
\hline \multicolumn{4}{|c|}{ Assistance from faith-based/charitable organisations } \\
\hline Yes & $79.3 \%$ & $68.2 \%$ & $11.1 \%$ \\
\hline No & $18.4 \%$ & $11.7 \%$ & $6.7 \%$ \\
\hline \multicolumn{4}{|c|}{ Type of organisations that provided support } \\
\hline Faith based organisation & $76.1 \%$ & $67.1 \%$ & $9.0 \%$ \\
\hline Charitable organisation & $19.9 \%$ & $12.4 \%$ & $7.5 \%$ \\
\hline
\end{tabular}

Source: Field data, (2018). Data are weighted by gender. The sample size varies for select variables due to missing values.

Respondents were requested to state how they secured material and financial support after release. Most receive it from friends $(45.4 \%)$. Family support is dismal $(8.5 \%)$, and support from ex-offender assistance programmes even worse (3.2\%). Poor family support strengthens the observation that few respondents received family visits during incarceration. This resonates well with the notion that close family exhibit rejection towards offending family. Rejection might contribute to increased recidivism, as offenders seek other avenues of acceptation. There are few organisations like Rodi Kenya, Muslims for Human Rights, and Ahadi Trust that avail ex-offender support.

Many respondents $(59.8 \%)$ have convicted family members, indicating that criminality is generally present in some families. Although this gives impetus to biological theories of criminal behaviour (holding that crime is an inherited trait), particularly among Kenyan male recidivists (Siegel \& Welsh, 2009: 143) other potential contributors should not be discarded.

Respondents indicate that neighbourhoods contribute to recidivism (35.1\% agree strongly). Neighbourhood characteristics might be significant in reoffending. Most respondents $(79.3 \%)$ indicate that they receive assistance from faith-based and charitable organisations, like the SDA Church, Rodi Kenya, Muslims for Human Rights, and Ahadi Trust (76.1\% specifying these organisations).

\subsubsection{QUALITATIVE ANALYSIS OF COMMUNITY PERCEPTION AND ATTITUDE ON RECIDIVISM}

We now present the findings from interviews and focus group discussions.

Interviews with probation and prison officers

Interviews with probation and prison officers reveal significant influence of community perception and attitude on potential recidivism. All 13 probation officers interviewed indicate that in probation reports, it is mandatory to determine whether immediate family, extended family, the victim and his/her family, neighbourhood, and the general community favour the offender's release. If they are receptive, release is recommended. Offenders who are accepted back are less likely to reoffend, as revealed through empirical studies (Murray \& Farrington, 2010: 641; Tenibiaje, 2013: 35; Qadri, 2005: 91; La Vigne, Lachman, Rao \& Matthews, 2004: 99; Martinez \& Abrams, 2013: 171; Bales \& Mears, 2008: 301).

Probation officers reveal that when the social enquiry shows that offenders are not wanted back, recidivism 
is higher. Offenders who engage in negative social interactions upon release were highly likely to reoffend, while interaction with known criminals also cause recidivism.

Labelling and tagging are common after release. People label ex-inmates and (sometimes wrongly) suspect them whenever neighbourhood crime occurs. Such negative labelling and tagging makes ex-offenders actualise society expectations. Therefore, labelling meaningfully impacts recidivism.

Prison officers argue that frequently visited offenders are less likely to reoffend. Less frequently visited or not-at-all visited offenders are more likely to recidivate. Prison officers explain that visitations provide reassurance of love, respect, and value.

Social interaction also has significant influence on recidivism, according to prison officers. Interaction with hard-core criminals during short periods of interaction reinforces reoffending tendencies.

Focus group revelations from family, victims, the community, local administration, and religious leaders Focus group discussions with families, victims, community members, local administration, and religious leaders seek to establish whether they believe that ex-offenders have improved since incarceration. Discussions elicited mixed signals and divided opinion, with some respondents arguing that offenders had changed. Offender family and community members show opposing perceptions, seeking justification to sustain their perceptions.

A priest at a local church in Shikangania had this opinion about a returned church member after one-year imprisonment for creating disturbance and a breach of peace:

"He has reformed and is no longer argumentative. He behaves well in church and supports activities. We have not heard of any frictions with the neighbours. He is generally well behaved" Shikangania village (30/6/2018).

A Kambi-ya-Mwanza villager commented as follows about the ex-offender who assaulted his young son and received six months imprisonment:

"He has never talked to us since his release three months ago. We don't know what he thinks. We did the right thing to report him injuring my son. We still live in fear given his aloof nature” Kambi-ya-Mwanza (29/6/2018).

Focus group interviews with families of recidivists and community members sought answers about labelling and tagging of offenders. Most offenders are labelled and tagged. Most respondents (54.7\%) believe in "once an offender always an offender" and view offenders as bad people who cannot change. A mother in Likuyani responded as follows about her offender son:

"He is a thief. I don't think he can change. Many items lost in this neighbourhood are stolen by him" Likuyani Market (2/7/2018) (the specific offender served twelve months imprisonment for theft. His family still labels him as a thief without tangible evidence).

Community members were asked about the effects of tagging and labelling offenders. Responses are mixed. Some argue that it affects, some are not sure, and others opine that tagging and labelling have no effect on reoffending. An Assistant-chief reacted as follows:

"People should not call ex-offenders criminals. Some of them reform and become law-abiding. Labelling and tagging can make them return to criminality" Shirere Sub-location, (29/6/2018).

A village elder from Roasterman reacted this way about labelling offenders:

"These offenders never change character. Prisons are universities where bad behaviour is learnt. Some that go there for petty offences graduate into hard-core criminals and commit capital offences later on" Roasterman $(2 / 7 / 2018)$.

A comparison of findings on the influence of community perception and attitude on recidivism is made between this study and similar studies. Using differential support and coercion as framework, social support prevents crime, but coercion is the main causal explanation for criminal behaviour (Colvin, Cullen \& Vander, 2002: 37; Colvin, 2000: 525).

Coercion also causes crime (Merton, 1958: 211). Aversive family interchanges and disciplinary patterns (constituting coercion) are the main sources of juvenile delinquency. These coercive interchanges include the use of physical and non-physical attacks (negative comments, critical remarks, teasing, humiliation, and threats). Physical abuse and coercive environments also cause criminal behaviour. Coercive control weakens and alienates the social bond, leading to persistent delinquent behaviour (La Vigne, et al., 2014: 344).

\subsection{SUMMARY}

Communities have a crucial role to play in ex-inmates' positive reintegration. There is a need for specific strategies to build and maintain community interest and participation in systems of assistance and oversight. There is a propensity for the public to depend heavily on oversight from the criminal justice system.

Re-entry identification for inmates is a technique aimed at promoting community involvement in helping ex-inmates transitioning into society. This reflects on the offender's interests, their communities, and neighbourhoods (Brazzell, 2007: 349). The key features of this strategy are enlisting public stakeholder aid and participation; developing diverse and complementary dissemination methods; and strategic communication to build a framework for positive community intervention.

According to Ward and Steward (2003: 669) strength-based approaches, based on the assumption that 
offenders have interests, abilities, and aspirations to achieve through the assistance of parents and the general society, resources can be mobilised to build capacity for offenders to reduce recidivism risks. It is based on adding values to the life of the offenders, rather than just removing or addressing the problems. Criminal behaviour, and in extension recidivism by released inmates, is partly a function of the lack of internal and external assistance to ensure pro-social behaviour upon release.

The study reveals a significant relationship between offender characteristics and recidivism. We recommend that correctional treatment plans should consider the individual offender characteristics, since there is strong association between individual characteristics and recidivism.

The investigation did not find a significant influence of sentence length on recidivism. Nonetheless, it is recommended that prison-based rehabilitation should take into account the imprisonment period to maximise the benefits for offenders.

Successfully reintegrated offenders record low levels of recidivism. The study recommends that Government and relevant stakeholders should integrate approaches that target successful re-entry. Such investment in reintegration should prevent recidivism.

There is a significant relationship between neighbourhood context and recidivism. Mentorship and empowerment programmes in neighbourhoods should be considered, along with improved neighbourhood designs, visible policing, and adequate social amenities.

\section{REFERENCES}

Ainsworth, P.B. 2001. Offender profiling and crime analysis. Devon: Willan.

Bales, W.D. \& Mears, D.P. 2008. Inmate social ties and the transition to society: Does visitation reduce recidivism? Journal of Research in Crime and Delinquency, Vol. 45(3), 287-321.

Benda, B.B. 2005. Gender differences in Life-Course Theory of Recidivism: A survival analysis. International Journal of Offender Therapy and Comparative Criminology. Vol. 49(3), 325-342.

Berg, M.T., \& Huebner, B.M. 2011. Reentry and the ties that bind: An examination of social ties, employment, and recidivism. Justice Quarterly. Vol 28(2), 382-410.

Brazzell, D. 2007. Informing and engaging communities through re-entry mapping. Washington (D.C.): Justice Policy Center.

Brown, S.L. 2012. The dynamic prediction of criminal recidivism: A meta-analytic comparison and methods of assessment. Journal of Criminal Justice and Behaviour, Vol. 36(6), 567-590.

Bushway, S. \& Reuter, P. 2002. "Labour markets and crime risk factors." In Petersilia, J. 2003. When inmates come home: Parole and inmate re-entry. New York: Oxford University Press.

Chiricos, T., Barrick, K., Bales, W., \& Bontrager, S. 2007. The labelling of convicted felons and its consequences for recidivism. Criminology: An Interdisciplinary Journal, 45(3), 547-581.

Colvin, M. 2000. Crime and coercion: An Integrated Theory of Chronic Criminality. New York: St. Martin's.

Colvin, M., Cullen, T., \& Vander, T. 2002. Coercion, social support and crime: An emerging theoretical consensus. Journal of Criminology 40(1), 19-42.

Cunneen, C. \& Luke, G. 2007. Recidivism and the effectiveness of criminal justice interventions. Current Issues in Criminal Justice, Vol. 19(2), 197-210.

Fhooblall, H. Chitto, B. \& Bholoa, A. 2011. Trends in incarceration and recidivism in Mauritius: Raising the alarm: Global Journal of Human Social Sciences, Vol. 11(7), 53-64.

Field, A. 2009. Discovering statistics using IBM Statistics, $3^{\text {rd }}$ Ed. London: Sage.

Fox, A. 2002. Aftercare for drug-using prisoners: Lessons from an international study. Probation Journal, 49(2), 120-129.

Garvin, E.C., Cannuscio, C.C., \& Branas, C.C. 2013. Greening vacant lots to reduce violent crime: A randomised controlled trial. Injury Prevention, 19(3), 198-203.

Hirschi, T. \& Rodney, S. 1969. Hellfire and Delinquency. Social Problems, 17(2), 202-213.

Holzer, H. 1996. What employers want: Job prospects of less-educated workers. New York: Russell Sage Foundation.

Hutcheson, D.G. \& Sofronious, N. 1999. The Multivariate Social Scientist: Introductory statistics using Generalised Linear Models. London: Sage.

Johnson, J.G., Cohen, P., Chen, H., Kasen, S, \& Brook, J.S. 2006. Parenting behaviors associated with risk for Offspring Personality Disorder during adulthood. Arch Gen Psychiatry. 63(5), 579-587.

Kenya National Bureau of Statistics. 2018. Economic Survey. Nairobi: Government of Kenya Press.

Kimani, P. 2016. Administration of the Kenya Prisons Organisation. $161^{\text {st }}$ International Training Course Participants' Papers. Tokyo: UNAFEI.

La Vigne, G., Lachman, P., Rao, S. \& Matthews, A. 2014. Stop and frisk, balancing crime control with community relations. Washington DC: Office of Community Oriented Policing Services.

Lievore, D. 2004. Recidivism of sexual assault offenders: Rates, risk factors, and treatment efficacy. A report 
prepared for the Office of the Status of Women. Canberra: Australian Institute of Criminology.

MacKenzie, D.L. 2006. What works in Corrections: Reducing the criminal activities of offenders and delinquents. New York: Cambridge University Press.

Maltz, M.D. 2001. Recidivism. Florida: Academic Press.

Martinez, D.J. \& Abrams, L.S. 2013. Informal social support among returning young offenders: A metasynthesis of the literature. International Journal of Offender Therapy and Comparative Criminology, 57(2), 169-190.

Merton, R.K. 1958. Social structure and anomie. In Haralambos, M. and Holborn, M. 1991. Sociology: Themes and Perspectives, London: Collins Educational.

Murray, J. \& Farrington, D. 2010. Risk factors for conduct disorder and delinquency: Key findings from longitudinal studies. The Canadian Journal of Psychiatry, Vol. 55(10), 633-642.

Obondi, C. 2011. Effective resettlement of offenders by strengthening community reintegration of factors: Kenya's experience. Tokyo: UNAFEI Publishers.

Olusanya, O., \& Gau, J.M. 2012. Race, neighbourhood context and risk prediction. Criminal Justice Studies, 25(2), 159-175.

Oruta, E.M. 2019. Correlates of recidivism among released prisoners, a study of Kakamega County, Kenya. Unpublished PhD Thesis. Pretoria: University of South Africa.

Oruta, E., Omosa, N. \& Lusire, L. 2017. The role of prison experience on recidivism in Kakamega County, Kenya. Journal of Public Policy and Administration Research. Vol. 7(5), 101-107.

Qadri, M. A. 2005. Criminology: Problems and perspectives. $5^{\text {th }}$ Ed. Delhi: East Book Company.

Republic of Kenya, 2012. Department of Correctional Services: Prisons Act. Nairobi: Government Press.

Republic of Kenya, 2012b. Department of Correctional Services: Probation of offender's Act. Nairobi: Government Press.

Rosario, J.D. 2010. Diagnosing crime: The failures of rehabilitation in the justice system. Available at https://borderzine.com/2010/08/diagnosing-crime-the-failures-of- rehabilitation-in-the-justice-system/ (accessed on: 2 June 2021).

Sampson, R.J. \& Laub, J.H. 1993. Crime in the making: Pathways and turning points through life. Cambridge: Harvard University Press.

Sarfin, R.L. 2021. 5 Characteristics of data quality. Available at 5 Characteristics of Data Quality - See why each matters to your business (precisely.com) (accessed on: 25 May 2021).

Scott, G. 2004. "It's a sucker's outfit": How urban gangs enable and impede the reintegration of ex-convicts. Ethnography, Vol. 5(1), 107-140.

Shoemaker, D. 2009. Juvenile delinquency. New York: Rowman \& Littlefield.

Siegel, L. 2010. Criminology: Theories, patterns, and typologies. Tenth Edition. Belmont: Wadsworth.

Siegel, L., \& Welsh, B. 2009. Juvenile delinquency: Theory, practice, and law. Belmont: Wadsworth.

Smith, M. 2018. Statistical analysis: A comprehensive handbook for statistical concepts, techniques and software tools. Edinburgh: Winchelsea Press.

Sounders, M., Lewis, P., \& Thornhill, A. 2009. Research methods for business students. New York: Pearson.

Sykes, G.M. 1958. The society of captives: A study of a maximum security prisons. Princeton: Princeton University Press.

Tenibiaje, D.J. 2013. Education attainment and peer group influence as predictors of recidivism. International Review of Social Sciences and Humanities, Vol 5(1): 30-37.

Visher, C.A. \& Travis, J. 2003. The transition from prison to community: Understanding individual pathways. Annual Review of Sociology, 29, 89-113.

Visher, C.A., Sara, A., Sherril, D. \& Yahner, J. 2005. Employment after prison: A longitudinal study of former inmates. Justice Quarterly, 28(5), 699-718.

Ward, T. \& Steward, C.A. 2003. The treatment of sex offenders: Risk management and good lives. Professional Psychology: Research and Practice, 34, 353-360.

Wasike, L.P. 2013. Factors influencing recidivism in government of Kenya prisons: The case of Meru Prison. Available at: LAISA PERTER WASKI FINAL PRESENTATION (uonbi.ac.ke) (accessed on: 17 May 2021).

Western, B., Kling, J.R. \& Weinman, D.F. 2001. The labor market consequences of incarceration. Crime and Delinquency, Vol. 47(3), 410-427. 